\title{
ARE LAWYERS REgULATABLE?
}

\section{DUNCAN WEBB ${ }^{*}$}

There is a long-standing debate surrounding whether the legal profession can be regulated, and if it can, to what degree self-regulation or co-regulation would be appropriate. This article focuses on the obstacles facing the regulation of the legal profession, such as: the nature of lawyers themselves and the types of services they provide; drafting challenges and the influence of lawyers on rule-making; self-governance; self-discipline; and reporting or enforcement challenges. The author suggests that these barriers may lead to ineffective regulation regardless of which model of regulation is used.
Il existe un long débat, à savoir si la profession juridique peut être régulée et, le cas échéant, dans quelle mesure l'autorégulation ou la corégulation conviendrait le mieux. Cet article porte sur les obstacles relatifs à la réglementation de la profession juridique, notamment la nature même des avocats et le type de services qu'ils fournissent; les difficultés de préparer les ébauches et l'influence des avocats en matière d'établissement des règles; l'autorégulation, l'autodiscipline et le signalement et l'exécution de problèmes. L'auteur laisse entendre que ces obstacles pourraient mener à une régulation inefficace peu importe le modèle utilisé.

\section{TABLE OF CONTENTS}

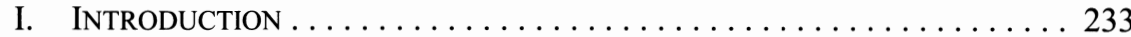

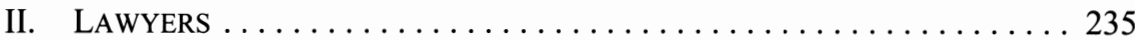

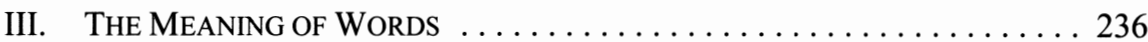

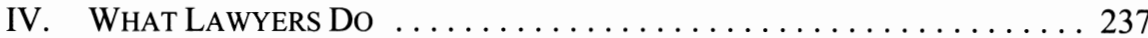

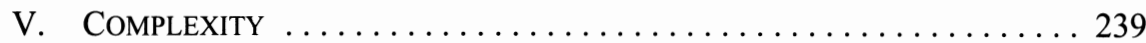

VI. Clear Rules, Fair Rules, or Complete Rules? . . . . . . . . . . 240

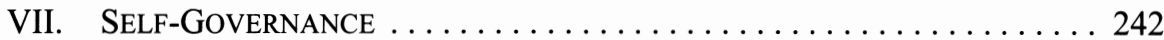

VIII. Role CONFLICT AND SELF-DisciPLINE $\ldots \ldots \ldots \ldots \ldots \ldots \ldots \ldots \ldots$

IX. RULE-MAKING . . . . . . . . . . . . . . . . . . . . . . . . . 248

X. REPORTING ............................ 249

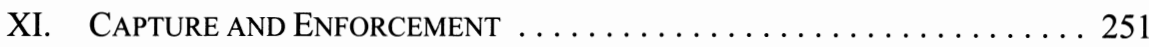

XII. CONCLUSION .......................... 253

\section{INTRODUCTION}

The title of this article is intentionally provocative, if also a little pessimistic. Considerable intellectual and professional energy has been poured into the question of regulation of the professions and of the legal profession in particular. ${ }^{1}$ The question usually posed is how the

Professor of Law, University of Canterbury, New Zealand; Barrister and Solicitor of the High Court of New Zealand.

See H.W. Arthurs, "The Dead Parrot: Does Professional Self-regulation Exhibit Vital Signs?" (1995) 33 Alta. L. Rev. 800; Richard Moorhead, "Self regulation and the market for legal services," online: (2004) Cardiff Centre for Ethics, Law and Society <http://www.ccels.cf.ac.uk/archives/publications/ 2004/moorheadpaper.pdf $>$; Carole Curtis, "Alternative Visions of the Legal Profession in Society: A Perspective on Ontario" (1995) 33 Alta. L. Rev 787; Gino E. Dal Pont, "Drafting Rules of Professional Conduct" (1996) N. Z. L. J. 313; E-DEC Limited, Purposes, Functions and Structure of Law Societies in New Zealand: Final Report to the New Zealand Law Society (Wellington: E-DEC Limited, 1997); Deborah L. Rhode, In the Interests of Justice: Reforming the Legal Profession (New York: Oxford University Press, 2000); Sir David Clementi, Review of the Regulatory Framework for Legal Services in England And Wales: Final Report (London: Department for Constitutional Affairs, 2004), online: 
profession is most effectively regulated. The associated debate generally circulates around whether, or to what degree, self-regulation is appropriate.

The international trend is away from self-regulation in favour of various models of coregulation, which some would say is an Orwellian term for a framework under which lawyers undertake all of the regulatory work subject to the supervision and shadow of intervention of government.

It is probably appropriate for me to take a moment to introduce myself and how I can claim to speak on a topic which is, at least on its face, so objectionable. I am a strange amalgam of both academic and practising lawyer. While primarily a professor of law whose main area of interest is ethics and professional responsibility, I also practice law in a midsized law firm. My practice is also non-typical in that it varies from highly commercial advisory work in areas such as securities and competition law, to appearances in appellate courts. It is in these capacities that I sit on the Canterbury District Law Society Council (being the governing body) of the local profession, as well as assisting with the disciplinary process by sitting on the New Zealand Law Society Ethics Committee, which is the gateway for all discipline and complaints in the profession.

Part of the background to these views is also the rapidly changing legal framework for lawyers practising in New Zealand. In 2006, Parliament swept away the old self-regulatory framework for New Zealand lawyers and introduced a regime under which the Minister of Justice has considerable powers of oversight and intervention. ${ }^{2}$ Part of this raft of reforms is a requirement for a significant redrafting of the relevant professional rules of conduct, including the incorporation of statutorily mandated principles of "client care" and certain fundamental obligations. This task was thought so unpleasant and unenviable that it was given to me. Over the past year or so, my eyes have been opened to the technical, professional, and political difficulties of drafting rules for lawyers.

From these various roles as academic, practitioner, drafter, regulator, and enforcer, I would like to discuss the hurdles to regulation of the legal profession and consider whether they are surmountable. As you will perhaps have gathered, my tentative conclusion is that the regulation of lawyers faces enormous barriers. It is, however, important to place this miserable suggestion in perspective. I am not suggesting that lawyers have conspired to create some regulation-free environment in which they can operate, nor am I suggesting that there is any particular factor which renders any attempt to regulate lawyers as nugatory.

Rather, this article takes the view that a cascade of obstructions, which have differing effects on the regulation of lawyers, when taken together, make the regulation of lawyers ineffective in any substantial way. Given the nature of the obstructions, it is arguable that this will be the case under any model of regulation.

Legal Services Review <http://www.legal-services-review.org.uk/content/report/reportchap.pdf> at 18 [Clementi, Review of Legal Services]; Joan Brockman, “An Update on Self-Regulation in the Legal Profession (1989-2000): Funnel In and Funnel Out” (2004) 19 C.J.L.S. 55 at 56.

2 Lawyers and Conveyancers Act 2006 (N.Z.), 2006/1. The Act has numerous other significant changes, including the introduction of a lay Legal Complaints Review Officer and the creation of a new profession of conveyancers. 


\section{LAWYERS}

To start with the obvious, lawyers are hard to regulate. Perhaps this is not quite as obvious as I assume. On a traditional analysis, lawyers are dream subjects. Law school inculcates lawyers with the values of the law and the legal system, and practice educates them in the culture of the law and their obligations as officers of the court and guardians of justice. On such a view, almost all lawyers will respond positively to the lightest regulation. Indeed, in living memory legal professions conducted their business without any written rules of conduct. This approach adopts an optimistic view of lawyers which may still be prevalent in some legal professions and is well documented. ${ }^{3}$ Indeed, there is thoughtful scholarship on the obligations of lawyers which has as its central thesis the obligation that in acting for a client is to understand and promote the objectives of the law. ${ }^{4}$ This is a view that is reflected in a number of jurisdictions' professional rules, including, by way of example, those of Alberta which provide that "[a] lawyer must respect and uphold the law in personal conduct and in rendering advice and assistance to others."

If, however, we put to one side the rhetoric which has been marshalled to explain and defend the position of the profession over the past hundred years, we know that lawyers serve their clients. In serving their clients, lawyers know how to do things with rules. Indeed, a central aspect of legal training is to make graduates "rule experts." Lawyers are effective because not only can they understand large bodies of rules (law) but also, they can apply them to complex fact situations and, where necessary, manipulate them to fit their client's circumstances.

Lawyers are "rule skeptics." That is to say that lawyers tend not look at rules with any awe or particular respect. Rather, we recognize that law is very much the product of human endeavour with all of its frailty and failings. While we may understand the concept of legitimacy and buy into the liberal democratic ideal including the rule of law, we know that law is negotiable. For example, we know that the sovereign words of Parliament can be vague, ambiguous, contradictory, and on occasion, largely meaningless. We also know that with sufficient will and organization, law can be changed in significant ways. While it would not be quite fair to say that lawyers view the law with contempt, I suggest that it is accurate to say that lawyers generally see the law for what it is - contingent, negotiable, and frequently flawed.

Given that lawyers view rules in this way, and have been trained largely to take advantage of rules for their clients, it is inevitable that lawyers will approach rules that govern their own conduct in a similar fashion. Indeed, when lawyers are measuring their own conduct against the rules that bind them, they are in a worse position, lacking the distance of an objective standpoint, from which to assess the legal (let alone ethical) merits of their position. ${ }^{6}$ In the

3 See e.g. W. Wesley Pue. "In Pursuit of a Better Myth: Lawyer's Histories and Histories of Lawyers" (1995) 33 Alta. L. Rev. 730.

W. Bradley Wendel, “Civil Obedience” (2004) 104 Colum. L. Rev. 363.

Law Society of Alberta (LSA), Code of Professional Conduct, online: LSA <http://www.lawsociety alberta.com/files/Code.pdf>, c. 1, r. 1 [LSA, Code of Conduct].

See Allan C. Hutchinson, Legal Ethics and Professional Responsibility (Toronto: Irwin Law, 1999) at 26. 
most egregious cases lawyers have made gross errors as to the applicability of professional standards, arguably believing that they were not breaching any obligations. ${ }^{7}$

The first hurdle for professional regulation is that lawyers are under no illusions as to the nature of the rules that bind them.

\section{THE MEANING OF WORDS}

The myth that words have a fixed and objective meaning has long been explored. Current discussions about language tend not to circulate around whether any given proposition represents some idea that exists independently of the audience, but rather the degree to which meaning and language is constituted by the speaker and listener respectively. ${ }^{8}$

One of the insights of the Critical Legal Studies movement was to recognize that the meaning of rules or rights depended not so much on how they were articulated, as on who spoke them, and who interpreted or applied them. ${ }^{9}$ In this sense, rules are indeterminate and, at least for some commentators, radically indeterminate in any objective way. ${ }^{10}$ Meaning is fixed in the political context in which the rule is applied, including the relevant power relationships. Even moderate commentators would accept that rules and their underpinning meaning are not stable, objective, or determinate in the formalistic way which had hitherto been maintained. ${ }^{11}$

In respect of professional regulation, this has meant that where discipline is left in the hands of the profession, conduct deserving of sanction has generally been found to be matters which are harmful to the profession at large, and action has generally been against professionals who sit at the margins of the profession. ${ }^{12}$ It does not matter if the triggering words for discipline refer to conduct which "is incompatible with the best interests of the public or of the members of the Society"13 or conduct "that would reasonably be regarded by lawyers of good standing as disgraceful or dishonourable." ${ }^{14}$ As long as the framework in which the meaning of these words is determined is one where lawyers form an important part of the interpretative community, or the interpretative community holds substantially the

See e.g. $R$. v. Murray (2000), 48 O.R. (3d) 544 (Sup. Ct.). In this case, it seems that the accused, a lawyer, believed that accepting a videotape, knowing it contained incriminating evidence with the obvious inference that it would therefore not fall into the hands of the police, raised no ethical issues. See also Randal N. Graham, "Moral Contexts" (2001) 50 U.N.B.L.J. 77.

Dennis Patterson, "From Postmodernism to Law and Truth" (2003) 26 Harv. J.L. \& Pub. Pol'y 49; Hilary Putnam, "Meaning and Reference" (1973) 70 Journal of Philosophy 699; Ferdinand de Saussure, Course in General Linguistics, ed. by Charles Balley \& Albert Sechehaye with the Collaboration of Albert Reidlinger, trans. by Wade Baskin (New York: Philosophical Library, 1959).

See e.g. Karl E. Klare, "Judicial Deradicalization of the Wagner Act and the Origins of Modern Legal Consciousness, 1937-1941”(1978) 62 Minn. L. Rev. 265.

10 See e.g. Duncan Kennedy, "Freedom and Constraint in Adjudication: A Critical Phenomenology" (1986) 36 J. Legal Educ. 518; Peter Gabel, "Reification in Legal Reasoning" in Steven Spitzer, ed., Research in Law and Sociology, vol. 3 (Greenwich: JAI Press, 1980) 25; Peter Gabel \& Jay M. Feinman, "Contract Law as Ideology" in David Kairys, ed., The Politics of Law: a Progressive Critique (New York: Pantheon Books, 1990) 172.

Robert W. Gordon, “Critical Legal Histories" (1984) 36 Stan. L. Rev. 57.

See Arthurs, supra note 1 at 805.

Legal Profession Act, R.S.A. 2000, c. L-8, s. 49(1)(a).

Lawyers and Conveyancers Act 2006, supra note 2, s. 7(1)(a)(i). 
same values as lawyers, their meaning will be constructed in a way which preserves the position of the legal profession.

In this sense, the regulation of the legal profession might be critiqued as doing the opposite of that which it purports to do. Many pieces of legislation regulating legal professions state their objectives as, in one way or another, constraining the activities of lawyers and requiring them to protect the public (sometimes referred to as consumers) or to promote the public interest (sometimes referred to as the administration of justice or the rule of law). ${ }^{15}$ On a skeptical view, the actual effect of such legislation in the hands of lawyers has been to leave lawyers free to conduct themselves largely free from the fetters of inconvenient regulation.

It should also be noted that lawyers may, on occasion be outright obstructive. Where the rules imposed are not seen as reasonable and legitimate constraints or obligations to be placed on lawyers, they may simply be ignored. Where such an approach is widespread, the regulation is rendered largely ineffective and arguably the effectiveness of the regulatory system as a whole is thrown into doubt. Thus when a requirement was imposed on English solicitors to have complaints handling systems, the professional response was observed by a commentator as follows: "The rule was either derided or misunderstood by a sizeable proportion of the profession. Resistance took various forms including non-compliance and a grudging compliance, through prolix and incomprehensible client care letters being sent to clients which perverted the aims of clarity and good communication."16

\section{WHAT LAWYERS Do}

There are a number of features regarding what lawyers do which render the regulation of the activities they undertake challenging. In some contracts for service, the outcome sought is some tangible product, whether it be a roof that no longer leaks or a car that does not make that strange rattling sound. A recurring feature in the profession is the fact that the benefit provided is intangible, and in many cases there may be no easily testable results. The fact that I am feeling better may or may not be due to the ministrations of my doctor, physiotherapist, or chiropractor; indeed, it may be despite their efforts. When the business I purchased does not live up to the expectations of the accountant's projections, there is unlikely to be any manifest error to be seen. Arguably, it is for the very reason that the services provided are beyond the understanding of the recipients that these professions are needed. In the absence of the respectability and credibility conferred upon and enhanced by the professional mantle, professionals, including lawyers, may have difficulty in persuading the public that the services we have to offer are valuable and necessary.

Lawyers' work is equally intangible. The quality of much legal work is largely unable to be tested by clients. If a case is lost before the courts, the blame will lie on the judge, the law, the evidence, the procedure, or perhaps the misdoing of the other party. A client who obtains

Moorhead, supra note 1 at 5-6 [footnotes omitted]. It seems a similar phenomenon was encountered in Ontario when an anti-discrimination rule was introduced into the Code of Professional Conduct in 1993.

See Curtis, supra note 1 at $788-89$. 
legal advice will rarely have the opportunity to have it tested, and even if this does occur by another opinion or in court, all it shows is that the other party was wrong: a testator has not yet successfully sued for a negligently drafted will.

Moreover, the work which a lawyer does is largely undertaken away from prying eyes. Even the conduct of litigation, which is often held up as that part of a lawyer's work most open to scrutiny, is in fact largely undertaken behind closed doors. The trial and other courtroom events are only a tiny part of the actual work.

Legal work often touches on matters which the clients would rather not talk about outside of the confines of a professional relationship. The reasons for this are various, including the personal or commercial sensitivity of the information, or the simple and understandable desire for privacy. In addition, when things go wrong, lawyers are the beneficiaries of a deep-seated reluctance on the part of individuals to confess that they have been duped or taken advantage of. This seems especially the case where the facts would suggest that the victim of the wrongdoing has (rightly or wrongly) acted foolishly.

The discussion of lawyers' work has largely looked at the inability of clients to measure lawyer competence, which some jurisdictions would not see as an issue of professional discipline in any event. When we turn to look at more traditional professional obligations, such as those of confidence and conflict of interest, it becomes apparent that clients are even less equipped to know whether their lawyer has acted properly. Indeed, in the case of professional breaches, the client may remain entirely unaware that an ethical issue has arisen, let alone that a breach has occurred.

Even if a professional issue is identified by the client or raised by the lawyer, the client is at an enormous disadvantage in assessing its significance. Consider a relatively common situation where partners in a business venture approach a lawyer to dissolve the partnership. The lawyer, having some sensitivity in such matters, will recognize that this is a conflict of interest and the presumption is that "[a] lawyer must not act for more than one party in a conflict or potential conflict situation unless all such parties consent and it is in the best interests of the parties that the lawyer so act." ${ }^{17}$ This can be explained to the clients. The lawyer might even note that it is fortunate that the parties are not at loggerheads as "[a] lawyer must not represent opposing parties to a dispute." ${ }^{18}$ The lawyer may even include in the deed of dissolution an explicit acknowledgement that before signing this agreement the parties were advised to and given the opportunity to seek advice as to the terms of the agreement and the dissolution of their partnership. ${ }^{19}$

In this subtle and quite probably wholly unintentional manner, lawyers can steer their clients through the necessary ethical waters to dock in what they (perhaps wrongly) view as a safe harbour. In many ways, the function of this exchange between lawyer and client on how to deal with the conflict is not about ensuring that the best interests of the parties are protected. Rather, it suggests to the client that there is no professional breach and assures 
lawyers that they are immune from professional reproach should their conduct be examined. Both lawyers and clients may be under considerable misapprehensions in this regard.

The fact is that the work of lawyers for clients touches on (sometimes very) private affairs. In addition, the nature of the work is such that clients are largely unable to determine whether the lawyer has done a decent job or adhered to the relevant professional standards. The end result is that much of the time any breaches that do occur are undetected and/or unreported.

\section{COMPLEXITY}

A further challenge for regulators is the fact that legal work is notoriously complex and diverse. The complexity of legal advice and decision-making cannot be overstated. Embedded in apparently simple questions are numerous variables of differing weight which make decision-making in such an environment so complex that they cannot be reduced to yes or no answers. Given the nature of legal problems and their practical context, it can be shown that it is impossible to distinguish between best solutions - even assuming there is one. Some matters are, in an objective sense, intractable. The problems that lawyers deal with on behalf of clients fall into this category. Even relatively simple legal problems are, in real terms, so complex that there is no way to discern conclusively which course of action is to be preferred.

This argument might be illustrated by a simple problem. Consider a simple transactional question: what is the best vehicle for the small business of a client and that client's spouse? We might see the options as something like sole trader, partnership, company, or trading trust. However, each of these has numerous permutations of its own. Should the company have only one director and shareholder? If there are two shareholders, do we need a shareholders' agreement? In answering these questions, the lawyer will need to take into consideration various factors with differing importance: the need for protection from creditors, the importance of separate legal identity, tax consequences, the clients' desire for simplicity, the compliance costs, the costs of implementation, and so on. The point is a mathematical one. Even with this simple question and relatively small numbers of options, the number of combinations is enormous. ${ }^{20}$ The consequence of this is that the effectiveness and appropriateness of a lawyer's advice is almost never testable.

This observation about lawyers' advice being untestable is equally true of the ethical decisions of lawyers. Indeed, that problem is arguably compounded by the fact that the ethical decisions of the lawyer are not open to the scrutiny of the client or in most cases any third party. Consider, for example, the question of whether a lawyer is faced with a conflict of interest between clients. The rule itself can be stated in relatively objective terms. For example, the Canadian Bar Association rule provides: "The lawyer shall not advise or represent both sides of a dispute and, except after adequate disclosure to and with the consent 
of the clients or prospective clients concerned, shall not act or continue to act in a matter when there is or is likely to be a conflicting interest." ${ }^{21}$ However, when the time comes to apply the rule, it is not at all clear what a conflict of interest is. Accordingly, the Code proceeds to explain in the commentary that "[a] conflicting interest is one that would be likely to affect adversely the lawyer's judgment on behalf of, advice to, or loyalty to a client or prospective client." 22

Therefore, a lawyer who is faced with the question has to ask whether the fact that he or she is proposing to act for two clients would be likely to adversely affect the lawyer's judgment on behalf of, advice to, or loyalty to a client. Lawyers who ask themselves these kinds of questions rarely conclude that their judgment is likely to be impaired by such conflicting obligations. However, even if a lawyer were able to approach the matter evenhandedly, the fact is that in all but the clearest of cases the question is too complex. Whether the conclusion reached by the lawyer is the right one is never testable (in the absence of hindsight). Rather, there are a range of conclusions which can be reached by the lawyer taking into account numerous considerations, each of which will appear justifiable.

The effect of this is that two parties to the same transaction may not elect to use the same lawyer where the lawyer is of the view that the interests of one party may adversely affect the way in which the other party is dealt with or where the advice and assistance of the lawyer may not be wholly independent. ${ }^{23}$ Not only does the lawyer decide whether the loyalty he or she can provide is adequate to meet the needs of the client and therefore the professional rules, but the decision is also effectively unchallengeable.

\section{Clear Rules, Fair Rules, or Complete Rules?}

Related to the problem of complexity is the continuing tension between fair rules and clear rules. Lawyers have a particularly pernicious predilection to draft in a way which anticipates all eventualities and seeks to deal with them appropriately. In a lawyer's view, the law fails when a situation arises which is not dealt with clearly by the relevant set of rules, or, arguably worse, is dealt with perversely. Of course, this means that whether rules be found in legislation, contracts, or codes of conduct, in many cases they are drafted in a highly detailed fashion. The consequence is that regulators are faced with a drafting dilemma. On the one hand, the enormous variety of human affairs means that it is impossible to be certain that some new and entirely unforeseen circumstances or matrix of circumstances won't arise which existing regulation does not effectively deal with.

On the other side of the ledger, if a rule is to be comprehensible, it must be drafted in a manner which captures the essence of the relevant obligations, is understandable, and is sufficiently flexible to accommodate all kinds of human relationships and dealings in a fair

21 Canadian Bar Association (CBA), Code of Professional Conduct (Ottawa: Canadian Bar Association, 2006), c. V [footnotes omitted] [CBA, Code of Conduct].

Ibid., c. V, cmt. 1 [footnotes omitted].

23 This is consistent with the long-standing observation that lawyers tend to assume systematically that a lawyer's view of what is the better course of action is a better guide for action and, as such and in this regard, lawyers tend to manipulate their clients in a paternalistic manner. See e.g. Richard Wasserstrom, "Lawyers as Professionals: Some Moral Issues" (1975) 5 Human Rights 1 at 19. 
manner. This leads to a tension between rules which are clear, rules which are complete, and rules which are fair. There is a compelling argument that any rule which satisfies one of these values necessarily sacrifices, to a greater or lesser extent, the others. ${ }^{24}$

The existing conflict of interest rule in New Zealand might be considered to be a rule which leans in favour of understandability rather than exhaustiveness in providing that:

In the event of a conflict or likely conflict of interest among clients, a practitioner shall forthwith take the following steps: advise all clients involved of the areas of conflict or potential conflict;

(iii) decline to act further for any party in the matter where so acting would or would be likely to disadvantage any of the clients involved. ${ }^{25}$

In contrast, Rule 3 of the English Solicitors' Code of Conduct 2007, ${ }^{26}$ which deals exclusively with conflicts of interest, adopts a more comprehensive approach, runs to some 34 pages, and deals in considerable detail with different kinds of transactions and how various conflicts ought to be dealt with. ${ }^{27}$

The problems of drafting such rules are well established. The New Zealand rule above may seem superficially clear, but it has considerable vagueness in the rule itself which lends the rule to considerable interpretation and over-interpretation. At its heart is the fact that nowhere is there clear guidance as to what constitutes a conflict of interest. The effect of such vagueness is that lawyers are at liberty to agree individually or between themselves what amounts to a conflict, which triggers the rule, and the end result is a liberal reading of the rule. The second obvious problem is the fact that a lawyer must cease acting only when to act would be "likely to disadvantage any of the clients." 28 Lawyers rarely recognize that their services are likely to disadvantage one or more of their clients. Indeed, the common professional presumption is that it would decidedly disadvantage the client for any lawyer other than themselves to act.

Conversely, the English approach has two distinct disadvantages. First, it unduly constrains lawyers as to when they may act in ways which draw distinctions that are largely arbitrary. So, for example, an English solicitor may not act in a conflict of interest situation;

For a comprehensive argument of this nature in respect of taxation, see John Prebble, "Ectopia, Tax Law and International Taxation" (1997) British Tax Review 383.

New Zealand Law Society (NZLS), Rules of Professional Conduct for Barristers and Solicitors, online: NZLS <http://www.nz-lawsoc.org.nz/PDFs/ROPC.pdf $>$, r. 1.07 [NZ, Rules of Conduct]. Solicitors Regulation Authority(SRA), Solicitors ' Code of Conduct 2007 (London: Law Society, 2007), online: SRA <http://www.sra.org.uk/documents/code/solicitors-code-of-conduct-full.pdf>.

See also CBA, Code of Conduct, supra note 21, c. V. It deals with "Impartiality and Conflict of Interest between Clients" and runs to a modest 20 pages.

Supra note 25, r. 1.07(1)(iii). 
however, he or she may act for both buyer and seller in a land conveyance, but only if both parties are established clients or the consideration is less than $£ 10,000$. However, the exception to this permission arises where the seller is a property developer. ${ }^{29}$ Such exceptions and distinctions are founded upon practice rather than upon any principle.

The second problem with such a detailed approach is that it seeks to regulate the conduct of lawyers as it is currently undertaken and has considerable difficulty in accommodating changing practices. The English rules are littered with references to particular idiosyncrasies of the practice of law in England. ${ }^{30}$ The most obvious problem with a single rule covering conflicts of interest extending to 34 pages is the fact that its length makes the rule largely incomprehensible and unlikely to be read and understood in advance. Certainly in so far as the rule impacts on client or consumers, it is unintelligible to them.

It does not matter where between the two extremes regulators situate rules. If the rules are framed as broad principles, they can be appropriated and interpreted by lawyers. If they are drafted in a comprehensive and detailed fashion, they will be unwieldy and full of cracks and holes which will be pounced upon where advantage can be obtained. This is not a case where the problem can be solved by reaching a suitable middle ground. A change in the degree of certainty over clarity simply alters the nature of the problem; it cannot obviate them.

\section{SELF-GOVERNANCE}

Traditionally, the ethical and professional rules that bound lawyers were made by lawyers themselves more or less universally across the Anglo-American system. While it is worth noting that the very existence of the profession depends on the imprimatur of the state, lawyers have been left to regulate themselves within this framework.

The tendency seems to have been to accept that the legal profession could govern itself in an essentially paternalistic manner with the public's interests at heart. Such a view is, however, very much in retreat internationally. It is suggested that few non-lawyers would now accept that the rules governing the incidents of the relationship between themselves and their lawyers ought to be drafted exclusively by lawyers. Perhaps more importantly, they do not believe lawyers have the necessary objectivity to make rules that do not lean towards self-interest.

Lawyers marshal numerous arguments of doubtful credence in favour of self-regulation. W. Wesley Pue's insightful piece on the role of myth and history in the culture of the legal profession ${ }^{31}$ recounts the importance this self-perception of the legal profession in Canada. While in Canada it appears that the model of professional self-regulation prevails, ${ }^{32}$ I can say

$29 \quad$ Supra note 26, r. 3.09, 3.10.

30 Ibid. Examples include deals with Solicitors' Estate Agency Limited (SEALs), limited liability practices, and Registered European Lawyers (RELs).

Pue, supra note 3.

Legal Profession Act, supra note 13: it appears typical that governance of the profession is undertaken by elected benchers with only modest membership of lay benchers appointed by the Minister. 
that where I come from, it is in fact no more; it has ceased to be. ${ }^{33}$ Its place has been filled with the euphemistically named "co-regulatory model" under which law societies implement rules and undertake professional discipline under the watchful eye and imminent intervention of the state. ${ }^{34}$ However, it is of considerable interest that under this impending co-regulatory model, lawyers still manage to dominate the rule-making process.

The enormous powers of persuasion and advocacy of lawyers are put to work in assuring non-lawyers in government and the wider community that little should change. It is argued that an independent legal profession, which acts autonomously from government, is needed to ensure the shibboleth of the "rule of law." It is maintained that for true equality before the law, and for the state to be subject to the ordinary law of the land, the legal profession needs to be free from state regulation. Such arguments are almost certainly made in good faith and with the conviction of the advocates, which makes them all the more persuasive. Their proponents are clear that the profession is a centrepiece of modern society and that any undermining of it would be positively harmful. This self-conviction may be attributable to the fact that lawyers, throughout their education and professional lives, are trained to see the law, the courts, and the associated professional institutions as necessary and fair. ${ }^{35}$ In this, uncritical law teachers must take their share of the blame. ${ }^{36}$

Advocates of self-regulation suggest that if the government were to make rules regarding professional conduct, it would not be possible to ensure the fearless advocacy and independent advice which is at the centre of the legal profession. Thus, we hear rhetoric opposing regulation protecting consumers of legal services:

The Government should not be able to use consumer rights as a cloak to attack people's basic civil liberty of having a genuinely independent lawyer acting on their behalf ... [H] aving a strong legal profession, independent of Government, is an important constitutional issue and improvements to the regulation of the legal profession should respect that. It is not in the consumer interest to have Government control over lawyers, because many consumers of legal services are taking cases against public authorities and the Government. $^{37}$

This argument is, however, of questionable force. The legal profession is subject to many statutory and common law rules as it is, and there is no suggestion that these rules limit the

Or to pay full homage to H.W. Arthurs, supra note 12: "Self-regulation has passed on! It is no more! It has ceased to be! It's expired and gone to meet its maker! It's a stiff! Bereft of life, it rests in peace! Pushing up the daisies! 'Is metabolic processes are now 'istory! It's off the twig! Its kicked the bucket, its shuffled off 'is mortal coil, run down the curtain and joined the bleedin' choir invisible!!" (with apologies to John Cleese \& Michael Palin, "Dead Parrot Sketch" performed on Monty Python's Flying Circus (1969)).

34 See e.g. Lawyers and Conveyancers Act 2006, supra note 2. See also the Legal Services Act 2007 (U.K.), 2007, c. 29: this $A c t$ further removes control of the regulatory and discipline functions from the legal professions in England and Wales. See also Legal Profession Act 2004 (N.S.W.): this is a typical Australian example.

35 The academy has played a significant part in developing and supporting this view of the profession. For one argument (and a scholarly analysis of similar views), see F.C. DeCoste, "Towards a Comprehensive Theory of Professional Responsibility" (2001) 50 U.N.B.L.J. 109.

36 Allan C. Hutchinson "Calgary and Everything After: A Postmodern Re-Vision of Lawyering" (1995) 33 Alta. L. Rev. 768 at 780.

37 U.K., H.C., Parliamentary Debates, vol. 461, col. 38 (4 June 2007) (Oliver Heald). 
independence of the practice and loyalty of advocates. In fact, lawyers depend on the state's authority, which has granted and protects the profession's privileged position. Lawyers are not the arbiters of justice - that is the role of the courts. While lawyers undeniably play an important role in the judicial process, they are simply assistants to the court. Moreover, the argument overlooks the fact that the advocacy role is only a part of the lawyer's role. Most of the profession's work is in non-litigious matters such as conveyancing, business transactions, and wills and estate administration. In such matters, a need for independence is not immediately apparent.

A weaker version of the independence argument is that professional rules are really only the business of lawyers, with no place for non-lawyer involvement. This approach has grown from the view that the rules of conduct were considered to be a voluntary code of conduct by which the organization's members set themselves higher professional standards than are required by the general law. No one would suggest that outside input is necessary into, say, a code of ethical conduct for mechanics. Such a code is an autonomous group's voluntary declaration of its intention to adopt certain standards. Indeed, many occupational groups commit themselves to voluntary codes of conduct.

This amounts to a claim that rules amount to an "honour code," which is the province of the profession's members and of no interest to outsiders. The problem with such an argument is that lawyers claim (and indeed have) a special role in society, which is considered of particular importance. Therefore, the rules of conduct lawyers adopt are of special importance. They are not mere customer service guidelines or best industry practice principles; rather, they are rules which ensure matters of fundamental importance, such as that anyone can have access to a lawyer, that a lawyer will deal with a client's affairs with loyalty, and that a lawyer will keep a client's information confidential. Further, the rules are more than a mere honour code. The rules the profession has created are a substitute for the rules the government would otherwise make.

Perhaps the most troubling argument for excluding non-lawyers from the legal profession's governance and rule-making is that they could not possibly understand the complexities of the law and legal practice. Such an argument plays into the public's common perception of lawyers as arrogant and patronizing. One commentator claims:

Even some of the basic tenets of professional responsibility are not understood by those lacking legal training. Consider the principle of partisanship. Judging by comments made in the media, and my own discussions with non-lawyers, many lay persons cannot understand, for example, how a lawyer can represent a person alleged to have committed an offensive crime, or a tobacco company defending a smoking suit. ${ }^{38}$

Such an argument is effectively an intellectual rolling of the eyes at non-lawyers with the assumption that if non-lawyers do not agree with the ethical precepts it is because, not being inculcated in the law, they cannot possibly understand the need for the rules. Few members of the public would deny that a lawyer's position in an adversarial system raises difficult ethical issues that require careful consideration. It may be that non-lawyers disagree with lawyers about how lawyers currently guide themselves in such matters, but this is not a 
reason for rejecting their opinions. In fact, the significant disjunction between the profession's view of proper conduct and the view of the public is a very good reason indeed for the legal profession to question whether it has got it right.

The legal profession is understandably reluctant to accept that its governance ought not to be solely in its members' hands. After all, until recently the profession has been allowed free rein over its rules and internal procedures. While historical precedent is a poor argument for maintaining the status quo, it is frequently dressed up in various guises and presented as a reason for resisting change. The profession's regulation by its members is touted as a venerable tradition that should be preserved. Alternatively, proponents of self-regulation claim the current system works sufficiently well, and it cannot be demonstrated conclusively that any replacement would improve matters.

Such arguments amount to no more than the retention of the current state of affairs because that is how things are and have always been. It can also be noted that the argument is founded on the shaky premise of a history of effective (or at least not defective) selfregulation. In fact, the history of the legal profession is the history of negotiation and accommodation between the state and the profession.

Other arguments in favour of the profession's self-regulation are based on pragmatism rather than principle. Some argue that the rules made by the profession to govern its members are more stringent than, or at least as stringent as, any rules that could reasonably be made by outsiders or with outside input. One reason given for this is the knowledge lurking in the minds of the rule-makers that if the profession makes lax rules, the public or the government would find this unacceptable and intervention would be inevitable. ${ }^{39}$

Alternatively, it is argued that better rules are made by self-regulation because of the profession's ethos and its desire to preserve its own high standards. It is suggested that lawyers have the greater interest in protecting the profession's reputation and are therefore harder on their own members than an impartial outsider would be. ${ }^{40}$ Such arguments do not, however, accord with how professional rules have developed.

Self-governance also seems fundamentally unfair. If we accept that the public and clients have an interest in the rules and their enforcement, then the fact that lawyers make the rules and enforce them against their members seems one-sided and procedurally unjust. The appearance of partisanship or bias is something lawyers are quick to recognize. However, in the matter of self-regulation, their own interest is claimed to be unobjectionable.

\section{$39 \quad$ Ibid.}

$40 \quad$ See Ysaiah Ross, Ethics in Law: Lawyers' Responsibility and Accountability in Australia, 3d ed. (Markham, Ont.: Butterworths Canada, 2001) at 103; Dal Pont, supra note 1; Robert Angyal \& Susan Payne, "The Law: Professional Autonomy and the Public Interest" in Paul Boreham, Alec Pemberton \& Paul Wilson, eds., The Professions in Australia: A Critical Appraisal (St. Lucia, Austl.: University of Queensland Press, 1976) 110; Philip Thomas \& Geoff Mungham, "Solicitors and Clients: Altruism or Self-interest" in Robert Dingwall \& Philip Lewis, eds., The Sociology of the Professions: Lawyers, Doctors and Others (New York: St. Martin's Press, 1983) 131 at 149. 


\section{ROLE CONFLICT AND SELF-DiSCIPLINE}

Lawyers in Anglo-American jurisdictions remain heavily involved in the discipline of members of the profession. In some cases, the lawyers manage all aspects of the process, other than that of a tribunal of final appeal which is reserved for the courts. In other cases, there is oversight by government or autonomous officers. However, the resources of the legal profession are inevitably marshalled to discharge what the Department of Constitutional Affairs' White Paper has called "front-line regulation." 41

In some cases, this means that the professional body has the dual role of protection of the public and the promotion of the interests of the profession. For a long time, the profession has been able to persuade government that these two aims are broadly consistent with each other. However, increasingly this notion is being rejected, as such an approach suggests that the tasks of a law society or bar association require the protection and promotion of members' (lawyers') interests to be balanced carefully with the protection of the public's interests in general and clients' interests in particular. For the professional body to discharge its roles effectively, it must act with a degree of objectivity when balancing these interests. This is difficult to expect when the organization's decision-makers are, by definition, predominantly, if not exclusively, lawyers.

No objection can be made to lawyers grouping together to promote and protect their interests in a guild-like manner. However, it is antithetical to expect the same organization, which is committed to its members' interests, to also act in the public's interest when regulating and disciplining its members. On numerous occasions, lawyers' interests and lay citizens' interests will diverge. Consequently, the two roles are fundamentally inconsistent with each other. This was well expressed in a report the New Zealand Law Society commissioned on its structure and functions. The report notes:

At present, law societies endeavour simultaneously to benefit the public, assist and protect lawyers' clients, assist lawyers as producers and advance lawyers' personal interests. These all are legitimate objectives. However, there are inherent conflicts between public and client interests, on the one hand, and lawyers' interests, on the other. Public and client protection involves regulating lawyers' behaviour, forcing lawyers to do what they might not otherwise have done. This imposes burdens on lawyers. In contrast, promoting lawyers' interests involves supporting lawyers in what they want to do and creating benefits for lawyers. This situation of conflicting regulatory and member interest objectives is well recognised by lawyers who have even given it a name, saying that law societies are required to be both policeman and friend. ${ }^{42}$

The protection of the public by the profession's self-regulation and peer discipline involves a conflict between the public's interests and the members of the profession's interests. Such a conflict is difficult to ignore. ${ }^{43}$ It is unreasonable to expect lawyers to devise

41 Department of Constitutional Affairs, The Future ofLegal Services: Putting Consumers First (London: Stationery Office, 2005) at 8.

$42 \quad$ E-DEC Limited, supra note 1 at para 3.4.

43 In Alberta, this tension can be seen in the definition of "conduct deserving sanction" in the Legal Profession Act, supra note 13, s. 49(1): "conduct deserving sanction is conduct that is (a) incompatible with the best interests of the public or of the members of the Society, or (b) tends to harm the standing of the legal profession generally." In New Zealand, the tension is more stark in the Law Practitioners 
rules other than those that are the most advantageous they can get away with. Obviously, the profession will not create ridiculously lax rules. If this were so, the public would lose confidence in the legal profession and government intervention would be inevitable. However, this does not detract from the fact that lawyers' self-governance can be expected to be in the lawyers' interest to the greatest degree possible without risking government intervention.

The inevitable result of regulation being left in the hands of the profession is that the profession is the focal point of the regulatory activity. Although lip service is paid to the importance of the public interest or the protection of clients, the inescapable fact is that the regulators know more about being lawyers than clients, and their minds naturally turn to the lawyerly aspects of regulations and discipline. ${ }^{44}$ This has been called the problem of lawyercentric regulation. ${ }^{45}$ One of the hallmarks of such lawyer centrism is the fact that regulatory bodies grind into action only in limited circumstances. These occur frequently when the conduct in question "tends to harm the standing of the legal profession generally" rather than when "the best interests of the public" are at risk. ${ }^{46}$ This means that discipline is more likely when the reputation (brand) of the profession is at risk, as in cases of lawyer dishonesty, where there are intra-professional disputes, such as lawyers using improper means to poach clients or innovative (but not permitted) business practices, or where third parties encroach on the monopoly of lawyers by engaging in the unauthorized practice of law. ${ }^{47}$

A number of jurisdictions have sought to avoid this "policeman and friend problem" by injecting a degree of independence into the regulatory framework. In England, the Law Society set up the Solicitors Regulation Authority as an autonomous agency overseen by an independent board. This was arguably an (unsuccessful) attempt to stave off further intervention in regulation. In New Zealand, the Lawyers and Conveyancers Act 2006 requires a bizarre bifurcation of the Society into a regulatory arm and a representative arm. ${ }^{48}$ Even in the new world of the English Legal Services Act 2007, the Law Society and Bar Council are the front line regulators with oversight by the independently appointed Legal Services Board. $^{49}$

None of these devices of separation of regulation and representation, or oversight, solve the problem that lawyers cannot be expected to promote the interests of the public at their own expense. To do so would be irrational, at least in a welfare economics sense. The only way in which this problem can be overcome is by genuine independent regulation, which is unlikely for a number of reasons. As has been observed, lawyers are highly persuasive in the political arena and will marshal compelling arguments for the status quo to remain. This

Act 1982 (N.Z.), 1982/123, s. 4: one of the functions of the Law Society is "[t]o promote the interests of the legal profession and the interests of the public in relation to legal matters."

See e.g. Rhode, supra note 1 at 143.

Clementi, Review of Legal Services, supra note 1 at 18.

Legal Profession Act, supra note 13, s. 49(1).

See Brockman, supra note 1 at 56.

Supra note 2, ss. 65-66. Under this arrangement, all lawyers must be members of the Society and pay levies for the regulatory function, but membership for the representative function is voluntary and by subscription. Levies may not be used to pay for any representative functions. 
model is likely to be acceded to because of the difficulty and cost of setting up a realistic and effective alternative.

\section{Rule-MaKing}

Regardless of whether the rules governing lawyers are made by lawyers independently, made by lawyers under supervision, or made by third parties, lawyers will always have an enormous amount of influence on the content and expression of the rules. Indeed, it is hard to contemplate rules being drafted in which the important drafting work was not undertaken or overseen by a lawyer.

In addition to the fact that lawyers are almost certainly to be found at the heart of any rulemaking process touching upon lawyers, it can also be observed that lawyers will organize articulate submissions to any political or quasi-political process. In New Zealand the progress of the Lawyers and Conveyancers Act 2006 may be instructive. The Act was passed after an extraordinarily long and difficult conception, gestation, and birth. The Lawyers and Conveyancers Bill, which was ultimately passed on 20 March 2006, was introduced in 2003. However, it was predated by a Conveyancers Bill that was introduced as a member's Bill by a member of the opposition (who later became the Minister of Justice) in the late 1990s. One reason for its slow progress was the fact that even prior to its introduction, the Law Society was engaging in vigorous discussions at the highest level of government, effectively negotiating the most advantageous possible regulatory framework. ${ }^{50}$ Similar engagements can be seen in the United Kingdom as the legal professions there undergo another tranche of reforms, this time with the introduction of a Legal Services Board as effectively an oversight regulator. ${ }^{51}$

The passing of legislation under which rule-making powers are taken away from the profession to a greater or lesser extent does not, of itself, mean that lawyers will lose control of rule-making. In general, where the government has intervened in the regulation of the profession, the actual rule-drafting function has been left in the hands of the profession. The government generally intervenes only on an approval or disallowance basis. ${ }^{52}$ This means that the rule-drafting process, which lawyers engage in such jurisdictions, becomes a delicate task of drafting rules which will not attract the attention of the regulator.

When rules are made, the legal profession and sectional interests within it will move to use whatever means are considered most effective to retain the privileges enjoyed. Indeed, in submitting to Sir David Clementi's Review of Legal Services, the Consumers' Association was frank in stating that: "In our view a 'strong and effective profession' is one that

50 This was particularly apparent in a letters from the president of the NZLS to all practitioners (15 September 1998; 20 October 1999) making proposals for the reform of the structure and role of the law society which cite governmental pressure for reform and observed that "further indecision would see the profession losing control of its own destiny."

Legal Services Act 2007, supra note 34.

$52 \quad$ See e.g. Lawyers and Conveyancers Act 2006, supra note 2, s. 101; Legal Profession Act 2004, supra note 34 , s. 714 . 
successfully exerts power and influence with decision-makers. The interests of the profession do not always coincide with the public interest." ${ }^{53}$

On such a view, it is the proper function of a professional organization to seek to protect member interests in respect of regulation, even at the expense of the public or consumers. Indeed, the Clementi Review recognized that a professional body tasked with representation of its members has an obligation to put its members' interests first. ${ }^{54}$ In some cases, this will be done by engagement in consultative processes. In many cases, drafters are happy to defer to those who confidently assert their expertise in the area. In other cases, the relationship will be more tense; argument may ensue as to what the powers of the regulator are and whether there is a mandate to erode the "constitutional" privileges of the profession.

In a formal sense, lawyers who are faced by supervision or intervention by the state are in a weak position. After all, they face the constitutional sovereignty of the legislator. However, in real terms, the legal profession still wields real and considerable power. Government does listen very carefully to the arguments of the legal profession. Certainly, governments rarely want to engage in outright conflict with lawyers. As such, rule-making becomes a delicate negotiation under the shadow of coercion on the one side and the less tangible threat of non-co-operation and disruption by the profession on the other. The result tends to be rules that change the position of lawyers only in non-fundamental ways.

\section{REPORTING}

One of the most obvious problems is the fact that lawyer breaches frequently go undetected. The only breaches that are likely to come to the attention of disciplinary bodies are those where the existence of the breach is clear and which have caused loss to clients or third parties. Many professional duties are breached in a way which is never discoverable. For example, a lawyer passing on confidential information to a related third party to take advantage of (for example, a buying client is unable to settle a real estate transaction and the property is likely to be on the market at a reduced price), is unlikely to ever come to light because the disclosure is hard to detect and there is no apparent loss to the client.

Further, clients may be aware of facts that give rise to a breach, but have no motivation to complain. For example, where a lawyer has acted in the face of a potential conflict of interest without consent, the parties may be entirely happy with the outcome, as the conflict never crystallized and no loss was suffered. Indeed, in hindsight the clients may be perplexed at the suggestion that there was a potential conflict at the outset. Such parties, who are often focused on effecting the transaction in question rather than the niceties of legal ethics, have no reason to complain and thereby trigger the enforcement mechanisms.

Even where there has been some loss or harm as a result of a lawyer's ethical breach, there are many compelling reasons not to take the matter further. Most obviously, a client who feels that he or she has been on the receiving end of lawyer misconduct may have a degree of skepticism that there is much to be gained from entering into a process which involves 
conflict with the same lawyer, particularly if the process is also run by lawyers. The client may also have quite reasonably resolved to put such matters behind them and engage in more constructive activity. In general, professional bodies will discourage formal complaints. It is generally considered to be a successful resolution if a potential complainant can be discouraged from actually initiating the formal complaints process. In this way, lawyeroperated complaints processes generally seek to "funnel" complaints out of the system at every opportunity. ${ }^{55}$

The individuals who are best placed to detect lawyer misconduct and to invoke the disciplinary process are other lawyers. There are, however, several reasons for lawyers not to report their colleagues except in the most serious cases. When the wrongdoer is a member of the same firm, or even a partner, to report the wrongdoing could have significant effects on the relationships in the firm and would cut across widely-accepted business values. It might also be seen as harming the health of the firm as a whole. Of course, if the wrongdoing is serious, such as defalcation or a gross breach of trust, the health of the firm may be enhanced by "outing" the wrongdoer, and there is unlikely to be any value left in the relationship worth preserving.

Where the wrongdoer is a lawyer in another firm, lawyers are still frequently reluctant to report the misconduct. Lawyers are generally unwilling to report colleagues with whom they must work on a day-to-day basis and from whom they may require indulgences in the future. One unattractive aspect of collegiality in the profession is the fact that it engenders a degree of insularity and protectiveness. Indeed, it is arguable that while there is a mandatory reporting rule, the underlying ethic in most professional bodies is to discourage such reporting and to encourage lawyers to resolve matters between themselves. ${ }^{56}$ The other reason that lawyers may not report wrongdoing is that there is a degree of empathy with the wrongdoer. This is especially so where the wrongdoing is in some sense understandable: such as incompetence under pressure, failing to be sensitive to a conflict of interest, or being overzealous for a client. In such cases, lawyers may well be of the view that it could just as well be them on the receiving end of a complaint for such conduct and are unwilling to put their colleague in such a predicament.

Almost all professional codes have rules which require lawyers to report the wrongdoing of other lawyers. The Law Society of Alberta's rule is, by international standards, quite stringent: "A lawyer must report to the Law Society any conduct of which the lawyer has personal knowledge and which in the lawyer's reasonable opinion, acting in good faith, raises a serious question about the competence, honesty or trustworthiness of another lawyer, or is likely to harm any person." 57

$55 \quad$ See Brockman, supra note 1.

56 See ibid. at 68, quoting the Chair of the Discipline Committee of the Law Society of Upper Canada.

57 LSA, Code of Conduct, supra note 5, c. 3, r. 4. Compare NZ Rules of Conduct, supra note 25, r. 6.03: Subject always to the rights and duties pertaining to practitioner and client privilege there is generally an obligation on every practitioner who has grounds to suspect defalcations or other improper acts by another practitioner to make a confidential report at the earliest possible time to the President or the Council of the District Society. 
It might be noted that while the rule is superficially expressed in mandatory terms, there are a number of qualifiers. Not only must the lawyer have personal knowledge of the wrongdoing, but there is also the triple-qualifier that (1) the lawyer must be of the opinion that there is a serious question of the person's competence, honesty, or trustworthiness; (2) the opinion must be "reasonably held"; and (3) the lawyer must be acting in good faith. Any lawyer worth his or her salt should be able to find enough doubt, either in the rule itself or amongst these qualifiers, to be able to conclude that the obligation to report is not triggered in any but the most egregious cases.

\section{Capture And Enforcement}

A common response to objections to the regulation and discipline of lawyers is to introduce non-lawyers into the system. Thus in Alberta, s. 11 of the Legal Profession Act requires that four benchers be lay members and, under s. 51, the lay benchers must sit on the Appeal Committee. ${ }^{58}$ Similar provisions exist in a number of other jurisdictions. ${ }^{59}$ The introduction of lay members into lawyer-dominated organizations has, predictably, had little effect on the regulation or discipline within the profession. The reasons for this have not been well-documented and the following comments are therefore speculation. ${ }^{60}$

My suggestion is that lay persons who are involved in the regulation of legal professions face considerable pressure to co-operate in significant ways with the profession. Where the lay person is a member of a regulatory body, that pressure will, simply by virtue of group dynamics, be immense. Even where the layperson is a regulator who is independent of the regulated profession, there will be considerable motivation to ensure a workable relationship between regulator and regulated.

The wider problem of regulatory capture has been recognized and documented. This is the phenomena whereby regulators over time increasingly advocate for the interests of the bodies they are tasked with regulating, rather than promoting the interests of the general public. ${ }^{61}$ Capture is a natural result of the development of a significant and ongoing relationship between the regulator and the regulated, in contrast to the sporadic contact that the regulator has with different members of the public. This can lead to the regulator having a detailed understanding of the problems facing the profession, without a counterbalanced

The Appeal Committee hears appeals from directions made by the Executive Director under s. 53(4)(a) dismissing a complaint: Legal Profession Act, supra note 13, s. 54.

See e.g. New Zealand's Law Practitioners Act 1982, supra note 43, ss. 96-97A, 108 (ss. 96-97A introduces lay observers who may comment on the discipline and complaints process, and s. 108 requires lay members to be appointed to the disciplinary tribunal); Ontario's Law Society Act, supra note 15, ss. $23,25.1(3)$ (s. 23 is couched in discretionary terms and states "[ $t$ ]he Lieutenant Governor in Council may appoint eight persons who are not licensees as benchers," and under s. 25.1(3) three lay benchers sit on the Paralegal Standing Committee).

But see Brockman, supra note 1 at 61 : it is suggested that lay benchers "inevitably tend to empathise and sympathise with the lawyers' point of view, at least so long as it is sensibly advanced" [footnotes omitted].

61 Jean-Jacques Laffont \& Jean Tirole, "The Politics of Government Decision-Making: A Theory of Regulatory Capture" (1991) 106 The Quarterly Journal of Economics 1089. 
understanding of the problems facing the public. Capture of this kind may also result from more concerted lobbying of an overt kind. ${ }^{62}$

While no self-respecting regulator would admit to having been "captured," there are some telltale signs. One is the under-enforcement of breaches, often allied with post hoc rationalizations, such as that it is better to preserve the relationships involved than to enforce trivial breaches or that the law is unclear and a prosecution should not proceed. This latter point is of course particularly apposite in the case of lawyer regulation where clear and unequivocal professional breaches seem to be rare indeed.

Once the disciplinary process is triggered, its effectiveness may also be questioned. The reluctance of lawyers and judges to make findings involving moral turpitude can be seen throughout numerous cases. In many jurisdictions, the complaints and discipline process requires a number of steps to be undertaken before any sanction is imposed. At each of these steps, the complaint may be dismissed as unfounded, not pursued, or not of sufficient gravity to warrant prosecution. ${ }^{63}$ In some cases, the sheer delay in dealing with the matter will render the complaints process largely meaningless. ${ }^{64}$

The difficulty in enforcing the rules in respect of professional breaches is compounded by the tendency of disciplinary bodies to subtly apply quasi-criminal procedural standards to the process. Although the function of the disciplinary tribunals bears some resemblances to the criminal process, professional discipline is quite distinct from a criminal process and this means that it is inappropriate to draw analogies between the two. The main distinction is that the function of the disciplinary process has no significant punishment element, and the focus of the proceeding should be to ensure the protection of the public. ${ }^{65}$ As such, there is no justification for the extraordinary procedural safeguards protecting the practitioner that would be found in the criminal law.

Accordingly, a lawyer accused of misconduct ought not to be treated as an accused "in whose favour the benevolent principle of English law makes all presumptions." ${ }^{\text {" However, }}$ when these matters are prosecuted by professional bodies, there is a strong tendency to make every presumption in favour of the lawyer. The more serious the charges, the stronger these

Michael E. Levine \& Jennifer L. Forrence, "Regulatory Capture, Public Interest, and the Public Agenda: Toward a Synthesis" (1990) 6:3 J.L. Econ. \& Org. 167.

63 In New Zealand, once a formal complaint is laid, a Council of the District Law Society or its Complaints Committee must consider whether the complaint is justified and the conduct is of sufficient gravity to bring charges. If it is, it will then fall to a tribunal to determine whether to find the charges proved and whether sanctions should be imposed: Law Practitioners Act 1982, supra note 43, Part 7. For the position in British Columbia, see Brockman, supra note 1 at 73.

See e.g. Legal Services Ombudsman, Annual Report and Accounts of the Legal Services Ombudsman for England and Wales 2006-2007 (London: Stationery Office, 2007) at 29: "Of the cases referred to OLSO by consumers the data shows that consumers continue to suffer significant periods of avoidable delay, either before, during or after the Law Society has commenced the investigation." A significant number of cases had been unresolved by the law society for in excess of two years.

$65 \quad$ New South Wales Bar Association v. Evatt (1968), 117 C.L.R. 177 (N.Z.H.C.).

${ }_{66}$ Thomas Erskine, The Speeches of Hon. Thomas Erskine (now Lord Erskine), When at the Bar, on Subjects Connected with the Liberty of the Press, and against Constructive Treasons, Collected by James Ridgeway (London: J. Ridgeway, 1810) vol. 2 at 91. 
presumptions will be.$^{67}$ It appears that this predilection to extreme caution in disciplining members, and the deference to every procedural safeguard, is known in Canada as well. ${ }^{68}$ This is proper in the criminal law where serious consequences of liberty may flow from an adverse finding. It might perhaps also be noted that in some workaday criminal cases a heavy onus of proof may pose few problems. However, the objective of professional discipline is not punishment, and the circumstances of the alleged wrongdoing are often disputed and hard to determine. The end result is that the common place quasi-criminal procedure applied to disciplinary proceedings is a further barrier to effective regulation.

\section{CONCLUSION}

This has been a miserable analysis of the legal profession. It has adopted a highly negative outlook and has ignored entirely the fact that the public is served exceedingly well by the legal profession almost all of the time.

This article has sought to show that the current framework of professional regulation is unlikely to change in a significant way any time soon. While reforms in some jurisdictions have been hailed or criticized as altering the foundations of the legal profession, it is the view of this author that nothing of substance has changed. Any meaningful change to the regulation of the legal profession faces significant barriers. These barriers are largely structural and do not presuppose that lawyers are necessarily obstructing or opposing change in any concerted or organized way. Changes to date have left the profession substantially in control of its own regulation and discipline, although in some cases formal power has been placed in the hands of independent third parties. Such change is incremental, peripheral, and does not alter the reality of lawyer-centric regulation.

Given who lawyers are, what they do, and the natural inclination to self-interest, regulation is difficult at best and arguably impossible to achieve in any meaningful way. The nature of lawyers' work means that most of what they do is never open to scrutiny, and clients are either motivated to be complicit in wrongdoing or have good reasons not to complain. In the event that a complaint is made, the issue is generally framed in terms of whether the lawyer has breached professional standards. Those standards are drafted and interpreted by lawyers who are sympathetic to the vicissitudes of legal practice and are wary of imposing unduly onerous duties on their fellows.

${ }^{67}$ Bhandari v. Advocates Committee, [1956] 3 All E.R. 742 (P.C.); B. v. Canterbury District Law Society, [2002] 3 N.Z.L.R. 113 (H.C.) at para. 58.

68 Stomberg v. Law Society of Saskatchewan (1996), 132 D.L.R. (4th) 470 (Q.B.). See also G. Mitchell, "Disciplining Lawyers for Serious Professional Misconduct - Is it possible after Stomberg v. Law Society (Saskatchewan)?”1996) 36 Admin. L.R. (2d) 213. 